\title{
Biosynthesis of Polyamide 4, a Biobased and Biodegradable Polymer
}

\author{
IWAN SASKIAWAN \\ Research Center for Biology, Lembaga Ilmu Pengetahuan Indonesia, \\ Jalan Raya Bogor-Jakarta Km. 46, Cibinong 16911, Indonesia \\ Phone: +62-21-8765066, Fax: +62-21-8765062,E-mail: iwansaskiawan@hotmail.com
}

\begin{abstract}
Polyamide 4, which is composed of repeating unit of $\gamma$-aminobutyric acid (GABA), is a biobased and biodegradable polymer since it can be synthesized from renewable material instead of fossil-based material. GABA is produced by decarboxylation of glutamate (Glu) using glutamate decarboxylase (GAD: EC 4.1.1.15), which is produced by some microorganisms. In this study, enzymatic conversion of GABA from glutamate by Lactococcus lactis and Escherichia coli cell and chemical polymerization of GABA to polyamide 4 were revealed. The results show that GAD activity of $E$. coli was higher than that of $L$. lactis. The treatment of $E$. coli cell by heating and sonication increased the GAD activity and conversion rate of glutamate to GABA was up to $70.5 \%$. The optimum temperature for this conversion is $37^{\circ} \mathrm{C}$. On the other hand, chemical synthesis of polyamide 4 was catalyzed by heating $\mathrm{GABA}$ at $215^{\circ} \mathrm{C}$ for 2 minutes.
\end{abstract}

Key words: polyamide 4, biodegradable polymer, $\gamma$-aminobutyric acid, glutamate decarboxylase

Much fossil fuel and its related resources have been and are being consumed to produce many kinds of products for human life. However, future reliance on fossil fuels has been questioned due to emerging concerns about greenhouse gas (GHG) emissions, particularly carbon dioxide $\left(\mathrm{CO}_{2}\right)$ and its potential contribution to global climate change (GCC) (Hansen et al. 2000; Woodruff et al. 2006). Recent study predicted that by 2100 the global average surface air temperature will be $1.4-5.8^{\circ} \mathrm{C}$ higher than in $1961-1990$. For that reason, it is important to take into account full implementation of plans to reduce fossil fuel use (Hebert 2005).

Consequently, there is a need to develop a bio-based product by using renewable materials as an alternative material to substitute fossil-based products. The one of biobased products is biopolymers. Utilization of biopolymers not only reduces the consumption of fossil-based material but also solves the disposal problem due to non-degradable petroleum based polymer as means of reducing the environment impact. Furthermore, the exploitation of abundant biomass resources to develop biopolymer is one of the solutions of solid waste accumulation problem. Representatives of biobased-biodegradable polymers are poly D- $\beta$-hydroxybutylate (PHB), poly L-lactide (PLA), well known as biodegradable plastic (Tokiwa and Calabia 2006) and poly amino acid (Obst and Steinbuchel 2004).

The other biobased-biodegradable polymer which has different structure is polyamide 4 also well known as nylon 4. Polyamide 4 is composed of repeating unit of $\gamma$-aminobutyric acid (GABA). Kawasaki et al. 2005 reported that polyamide 4 can be biodegraded in an activated sludge. On the other hand, polyamide 4 has good prospect as a novel bio-based polymer because it is synthesized from 2-pyrrolidone, a lactam of GABA, which can be made by means of decarboxylation of glutamate. This synthesis was catalyzed by glutamate decarboxylase (GAD). The synthetic route for biodegradable polyamide 4 was shown in Fig 1. At first, biomass is saccharified to produce glucose. Then it was fermented by coryneform bacteria (eg: Corynebacterium glutamicum) to produce glutamate. Using microbial GAD, the glutamate was decarboxylated to become GABA. Finaly, the monomer unit of GABA was heated to produce 2-pyrrolidone and chemically polymerized to produce polyamide 4.

This paper described the study on biosynthesis of polyamide 4 . It covers the synthesis of GABA using microbial GAD of Lactococcus lactis and Escherichia coli under different conditions and the chemical synthesis of polyamide 4 from GABA.

\section{MATERIALS AND METHODS}

Bacterial Strain. A wild type L. lactis NBRC 100933 and $E$. coli NBRC 3806 were obtained from National Institute of Technology and Evaluation-Biological Resource Center (NBRC), Japan. L. lactis NBRC 100933 was grown in medium no. 310 containing $10 \mathrm{~g} \mathrm{l}^{-1}$ peptone, $10 \mathrm{~g} \mathrm{l}^{-1}$ meat extract, $5 \mathrm{~g} \mathrm{l}^{-1}$ yeast extract, $20 \mathrm{~g} \mathrm{l}^{-1}$ glucose, $1 \mathrm{~g} \mathrm{l}^{-1}$ Tween 80, $2 \mathrm{~g} \mathrm{l}^{-1}$ $\mathrm{K}_{2} \mathrm{HPO}_{4}, 5 \mathrm{~g} \mathrm{l}^{-1} \mathrm{CH}_{3} \mathrm{COONa}, 2 \mathrm{~g} \mathrm{l}^{-1} \mathrm{C}_{6} \mathrm{H}_{14} \mathrm{~N}_{2} \mathrm{O}_{7}, 0.2 \mathrm{~g} \mathrm{l}^{-1}$ $\mathrm{MgSO}_{4} \cdot 7 \mathrm{H}_{2} \mathrm{O}, 0.05 \mathrm{~g} \mathrm{l}^{-1} \mathrm{MnSO}_{4} \cdot n \mathrm{H}_{2} \mathrm{O}, \mathrm{pH}$ 6.0-6.5. E. coli NBRC 3806 was grown in medium no. 802, which contains $10 \mathrm{gl}^{-1}$ polypepton, $2 \mathrm{~g} \mathrm{l}^{-1}$ yeast extract, $1 \mathrm{~g} \mathrm{l}^{-1} \mathrm{MgSO}_{4} \cdot 7 \mathrm{H}_{2} \mathrm{O}$, diluted in distilled water.

Rapid Glutamate Decarboxylase (GAD) Assay. One ml of seed culture of L. lactis NBRC 100933 growing in medium no. 310 was transferred to $50 \mathrm{ml}$ of TYGG medium $\left(5 \mathrm{~g} \mathrm{l}^{-1}\right.$ tryptone, $5 \mathrm{~g} \mathrm{l}^{-1}$ yeast extract, $10 \mathrm{~g} \mathrm{l}^{-1}$ glucose and $10 \mathrm{mM}$ glutamic acid) in $300 \mathrm{ml}$ flask and incubated for $24 \mathrm{~h}$ at $30^{\circ} \mathrm{C}$ in a shaker on $180 \mathrm{rpm}$. The cells were harvested by centrifugation at $1800 \mathrm{xg}$ for $20 \mathrm{~min}$ at $4^{\circ} \mathrm{C}$ and washed once with PBS $(0.15 \mathrm{M} \mathrm{NaCl}, 10 \mathrm{mM}$ sodium phosphate, $\mathrm{pH} 7.3)$. GAD activity assay was carried out using GAD reagent (Rice et al.1993). The GAD reagent consisted of $1 \mathrm{~g} \mathrm{l}^{-1} \mathrm{~L}$-glutamic acid, $0.05 \mathrm{~g} \mathrm{l}^{-1}$ bromocresol green (colorimetric indicator), $90 \mathrm{~g} \mathrm{l}^{-1}$ of $\mathrm{NaCl}$ and $3 \mathrm{ml}$ of TritonX-100 per liter. After the wash step, the cells were transferred to a test tube, $1 \mathrm{ml}$ of 


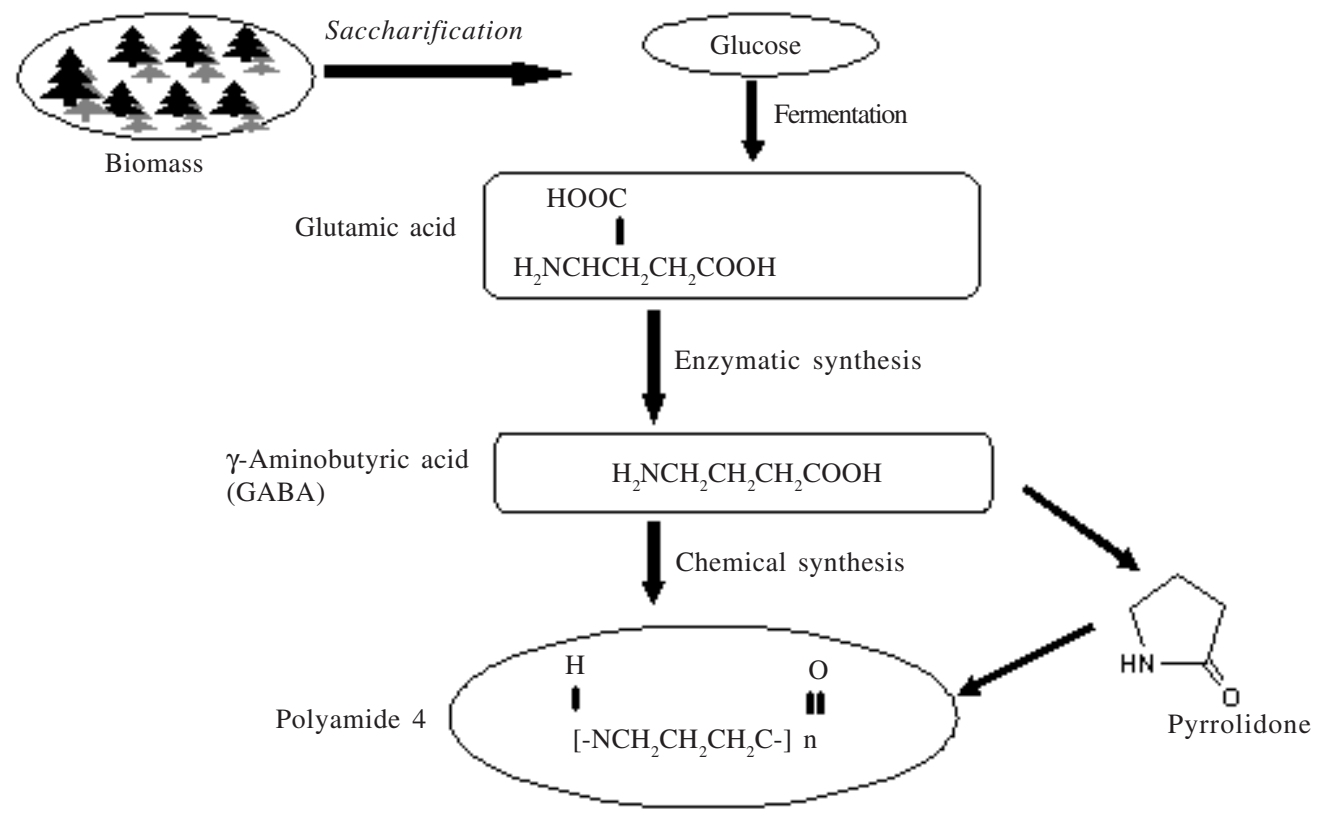

Fig 1 The biosynthetic route of polyamide 4 synthesis, a biobased and biodegradable polymer.

GAD reagent was added, mixed immediately, and vortexed vigorously for 30s. The tube was then incubated in a water bath at $35^{\circ} \mathrm{C}$ and observed hourly for $4 \mathrm{~h}$. A distinct change from yellow to blue was considered as a positive response of GAD activity. The similar method for GAD activity assay was also applied for of E. coli NBRC 3806.

GAD Activity Assay. The determination of GAD activity assay of L. lactis NBRC 100933 was referred to the method of Nomura et al. (1999) with minor modification. The cell suspension of L. lactis NBRC 100933 was frozen at $-50^{\circ} \mathrm{C}$ and lyophilized. For the enzyme assay, the cell powder was suspended in $1 \mathrm{ml}$ of $\mathrm{mM}$ sodium acetate buffer ( $\mathrm{pH} 4.7$ ). The reaction mixture for GAD activity assay consisted of $50 \mu \mathrm{l}$ of $4 \mathrm{mM}$ glutamate in $0.1 \mathrm{M}$ sodium acetate buffer (pH 4.7), $25 \mu \mathrm{l}$ of $0.4 \mathrm{mM}$ pyridoxal phosphate (PLP), $10 \mu \mathrm{l}$ cell powder suspension and $15 \mu \mathrm{l}$ of distillated water. The reaction was carried out for $8 \mathrm{~h}$ at $30^{\circ} \mathrm{C}$. One katal of GAD was defined as the amount of enzyme required to produce 1 mol GABA s- 1 at $30^{\circ} \mathrm{C}$ and $\mathrm{pH} 4.7$.

The cell preparation of E. coli NBRC 3806 and measurement of its GAD activity were carried as refered by Plokhov et al. (2000). E. coli NBRC 3806 was grown in a

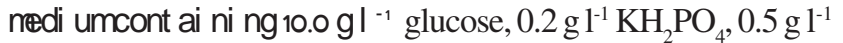
$\mathrm{MgSO}_{4}, 1.0 \mathrm{~g} \mathrm{l}^{-1}\left(\mathrm{NH}_{4}\right) \mathrm{Cl}$ and $20 \mathrm{~g} \mathrm{l}^{-1}$ peptone in distillated water ( $\mathrm{pH} 7$ ). After incubation for $48 \mathrm{~h}$, the cell was harvested by centrifugation at $40000 \mathrm{xg}$ for $20 \mathrm{~min}$ at $4^{\circ} \mathrm{C}$. The obtained wet cell biomass was frozen at $-20^{\circ} \mathrm{C}$. Five milligrams of wet cells were introduced to $12.5 \mathrm{ml} 0.9 \% \mathrm{NaCl}$ and stirred with a magnetic stirrer for $15 \mathrm{~min}$. This suspension was then divided into 2 equal portions. The first portion was incubated for at $53^{\circ} \mathrm{C}$ for $45 \mathrm{~min}$ and sonication at $1 \mathrm{~min}$, while the second portion was not treated by heating and sonicated. Furthermore, both portions were centrifuged at $5000 \mathrm{xg}$ for $10 \mathrm{~min}$. The pellets finally were diluted in $2.5 \mathrm{ml} 50 \mathrm{mM}$ sodium acetate buffer ( $\mathrm{pH} 4.7)$. These solutions were used for GAD activity assay.
The reaction mixture for GAD activity assay of $E$. coli NBRC 3806 consisted of $50 \mu 14 \mathrm{mM}$ glutamate in $0.1 \mathrm{M}$ sodium acetate buffer ( $\mathrm{pH} 4.7$ ), $25 \mu 10.4 \mathrm{mM}$ pyridoxal phosphate (PLP), $10 \mu$ l enzyme solution as prepared above and $15 \mathrm{ml}$ of distilled water. The reaction was carried out at various incubation times at $30^{\circ} \mathrm{C}$ and terminated by the addition of $30 \mu \mathrm{l} 30 \% \mathrm{NaOH}$ solution. The enzyme activity was expressed in units. One unit was defined as the amount of enzyme required to produce $1 \mu$ mole GABA in $1 \mathrm{~min}$ at $37^{\circ} \mathrm{C}$. GAD specific activity was expressed in $\mathrm{U} \mathrm{mg}^{-1}$ cell (wet weight).

GABA Analysis by High Performance Liquid Chromatography (HPLC). Standard sample contained $2.5 \mu \mathrm{M}$ and $5 \mu \mathrm{M}$ of Glu-GABA. A $20 \mu \mathrm{l}$ of the sample was dried using vacuum system. Then, it was added with $20 \mu \mathrm{l}$ TEA solution (ethanol: $\mathrm{H}_{2} \mathrm{O}$ :triethylamine $=2: 2: 1$ ) and evaporated by vacuum system for $10 \mathrm{~min}$. The dried sample then was added by $20 \mu 1$ of PITC solution (ethanol: $\mathrm{H}_{2} \mathrm{O}$ :TEA:PITC $=7: 1: 1: 1$ ) and vortexed for $20 \mathrm{~min}$ at $25^{\circ} \mathrm{C}$. Furthermore, the sample was dried using vacuum system and dissolved in $200 \mu \mathrm{l}$ phase A solution $(6 \%$ acetronitrile in $60 \mathrm{mM}$ sodium acetate buffer $\mathrm{pH} 6.0$ ). The solution was then filtered using $0.45 \mu \mathrm{m}$ filter.

HPLC was performed using reverse-phase column Wakosil PTC $(200 \times 4.0 \mathrm{~mm})$ at $1 \mathrm{ml} \mathrm{min}^{-1}$ flow rate. Two mobile phase were employed, $6 \%$ acetronitrile in $60 \mathrm{mM}$ sodium acetate buffer at $\mathrm{pH} 6.0$ and $60 \%$ acetronitrile. Detection was conducted at ultra violet spectrum $(\lambda=254 \mathrm{~nm})$.

Preparation of Pyrrolidone from GABA. 2-Pyrrolidone, a monomer of polyamide 4 is a lactam that is produced by the cyclization of GABA. It is synthesized by dehydration of GABA. A sum of 10 mmol GABA were placed in roundbottom flask equipped with magnetic stirrer. The GABA was then heated at high temperature on oil bath under inert atmosphere until gas-bubbling stops. The products were analyzed with the Jeol ECA-500 NMR spectrometer in D2O solution. 
Polymerization of Pyrrolidone. The method of polymerization of pyrrolidone was referred to Kawasaki et al. (2005). A mixture of 2-Pyrrolidone (17 g, $200 \mathrm{mmol}$ ) and sodium (138 mg, $6 \mathrm{mmol}$ ) were put in round-bottom flask equipped with magnetic stirrer. The mixture was heated to $50^{\circ} \mathrm{C}$ using oil bath under reduced pressure. After the sodium was reacted completely with 2-pyrrolidone, sebacoyl chloride (583.5 $\mathrm{mg}, 1.5 \mathrm{mmol}$ ) was added into the flask and was maintained at $50^{\circ} \mathrm{C}$ under reduced pressure for about $3 \mathrm{~h}$. The polymerization mixture was dissolved in formic acid and precipitated in acetone followed by washing with water and with methanol. NMR spectrum was obtained from chloroform/ formic acid solution $(95 / 9 \%)(\mathrm{v} / \mathrm{v})$.

\section{RESULTS}

Production of GABA by Microbial GAD of Lactococcus lactis and Escherichia coli. The results of the rapid GAD activity assay of L. lactis and E. coli was shown in Fig 2. The tube containing $E$. coli cell in GAD reagent show a darker blue color, suggesting that $E$. coli has higher GAD activity than that of L. lactis. GAD activity of E. coli NBRC 3806 cells with heating and sonication treatment was $4.15 \mathrm{U} \mathrm{mg}^{-1}$ cell, (wet weight) and the GAD activity without treatment was $3.81 \mathrm{U} \mathrm{mg}^{-1}$ cell (wet weight).

Furthermore, we attempted to synthesize GABA using L. lactis and E.coli on medium TYG. The results showed that after $16 \mathrm{~h}$ incubation the production of GABA using E. coli $\left(678.1 \mathrm{mg} \mathrm{l}^{-1}\right)$ was higher than that using L. lactis (178.8 $\mathrm{mg}^{-1}$ ) (Fig 3). This result seems to be corresponding with the previous result of rapid GAD activity assay. However, the addition of $10 \mathrm{mM}$ glutamate on TYG medium had no effect in enhancing GABA production. On the other hand, the rate and level of $E$. coli grown on TYG medium was also higher than those of L. lactis (Fig 4).

To optimize the enzymatic production of GABA by GAD of $E$. coli, it is important to reveal the substrate specificity of the enzyme. Fig 5 shows the conversion of various glutamate-containing substrates to GABA by $E$. coli. The result shows that the highest conversion $(70.5 \%)$ is obtained using L-glutamic acid. The lowest conversion (3.82\%) was obtained on $\mathrm{L}$-glutamate $\mathrm{HCl}$ substrate.

The effect of temperature on the reaction rate to produce GABA was also studied. The result showed that the reaction

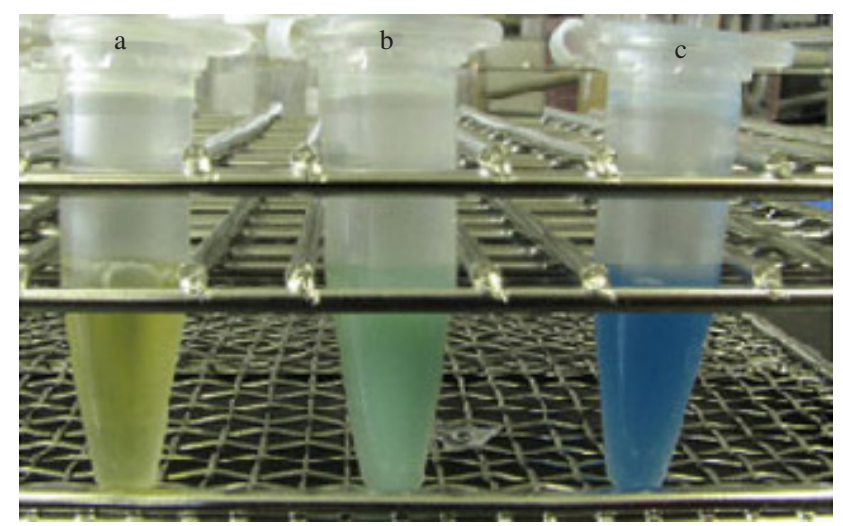

Fig 2 Rapid GAD assay. a, GAD reagent as a control; b, GAD reagent with Lactococcus lactis cell and c, GAD reagent with Escherichia coli cell.

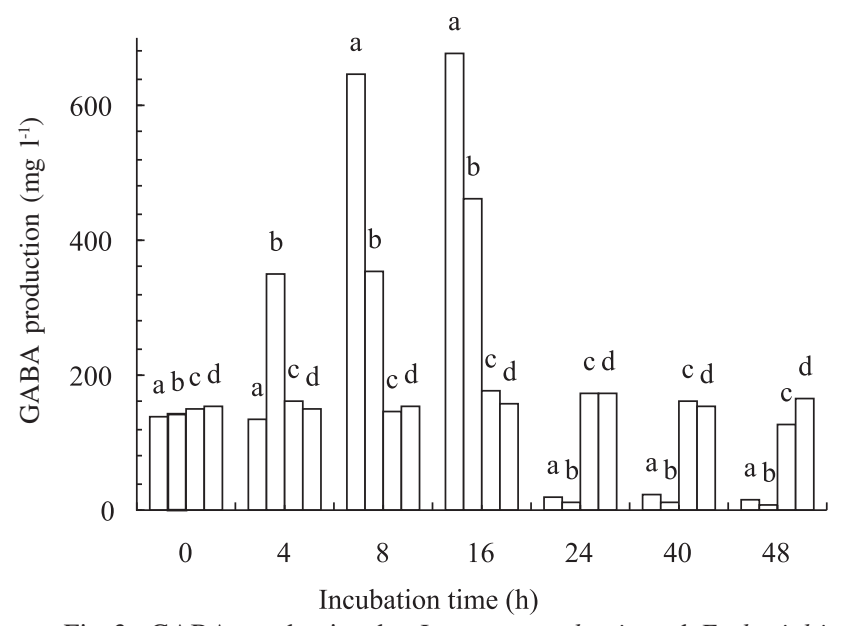

Fig 3 GABA production by Lactococcus lactis and Escherichia coli on TYG medium with addition of $10 \mathrm{mM}$ glutamate. a, E. coli on TYG medium; b, E. coli on TYG medium with addition of $10 \mathrm{mM}$ glutamate; c, L. lactis on TYG medium; d, L. lactis on TYG medium with addition of $10 \mathrm{mM}$ glutamate.

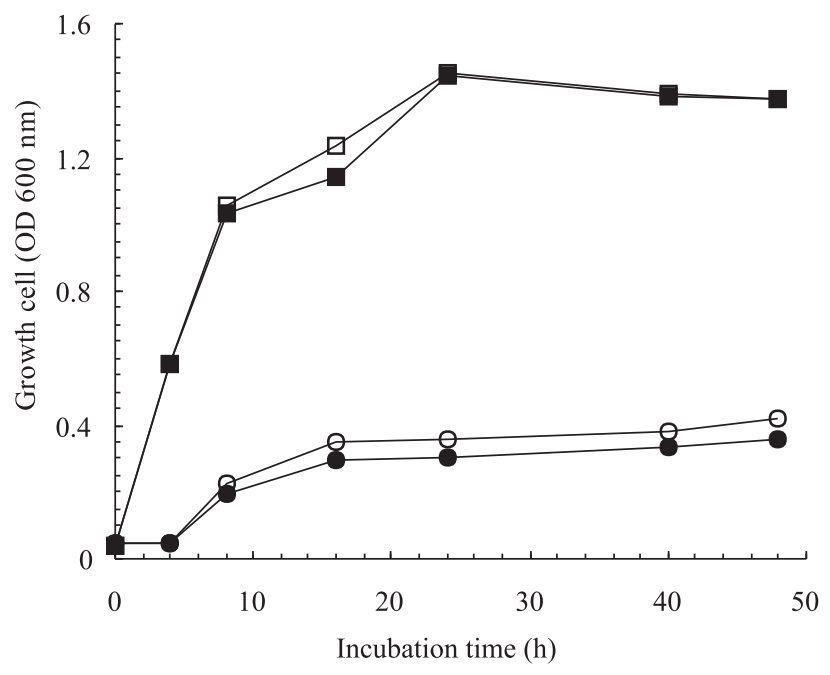

Fig 4 Cell growth of Lactococcus lactis and Escherichia coli on TYG medium with addition of $10 \mathrm{mM}$ Glutamate. $\mathbf{m}$ E. coli on TYG medium; $\square$, E. coli on TYG medium with addition of $10 \mathrm{mM}$ Glutamate; -, L. lactis on TYG medium; O, L. lactis on TYG medium with addition of $10 \mathrm{mM}$ glutamate.

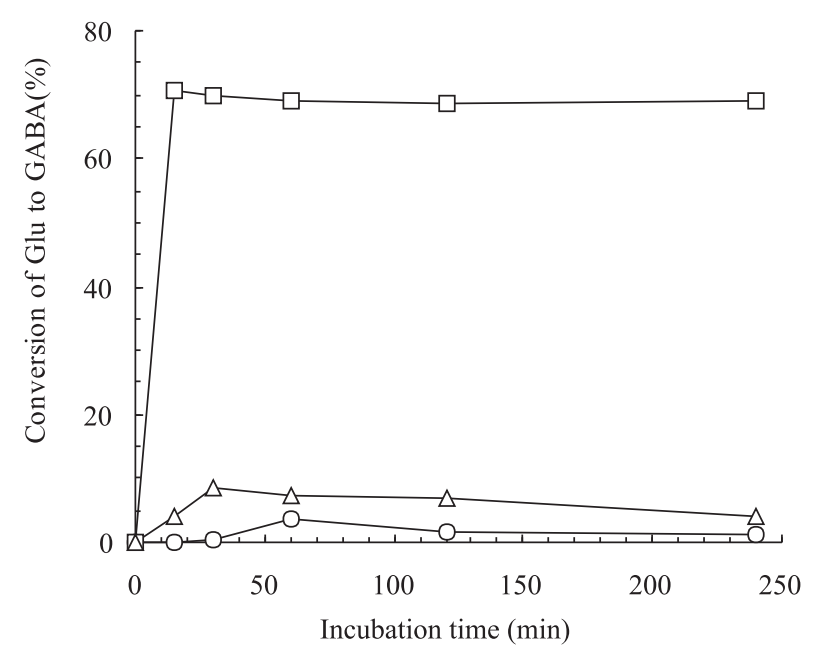

Fig 5 Glutamate-containing substrate specificity of GAD of

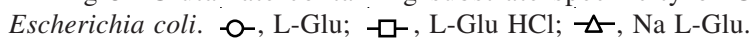


rate on incubation at $30^{\circ} \mathrm{C}, 37^{\circ} \mathrm{C}$ and $50^{\circ} \mathrm{C}$ were similar. On the other hand, the conversion rate of glutamate to GABA was decreased when the reaction was carried out at $70^{\circ} \mathrm{C}$ (Fig 6).

Chemical Synthesis of Polyamide 4. The chemical synthesis of polyamide 4 was initiated by preparation of pyrrolidone, a monomer unit of polyamide 4 . The gasbubbling in a flask containing GABA stopped when it was heated on $215^{\circ} \mathrm{C}$ for 2 min. Fig 7 shows $1 \mathrm{H}$ NMR spectra of the product and GABA. The spectrum displays characteristics signal for the methylene protons (b, c, a) of GABA at chemical shifts of 1.8, 2.2 and 2.9 ppm (Fig 7a), and characteristics signal for the methylene protons (b, c, a) of pyrrolidone at chemical shifts of 2.1,2.3 and 3.3 ppm (Fig 7b).

Furthermore, the crude polyamide 2 was washed with methanol and applied in $1 \mathrm{H} \mathrm{NMR}$ analysis. The spectra illustrate that washing the crude polyamide 4 with methanol effectively removes the remaining pyrrolidone (Fig 8).

\section{DISCUSSION}

GABA is an important ubiquitous non-protein amino acid in both prokaryotic and eukaryotic organisms and is

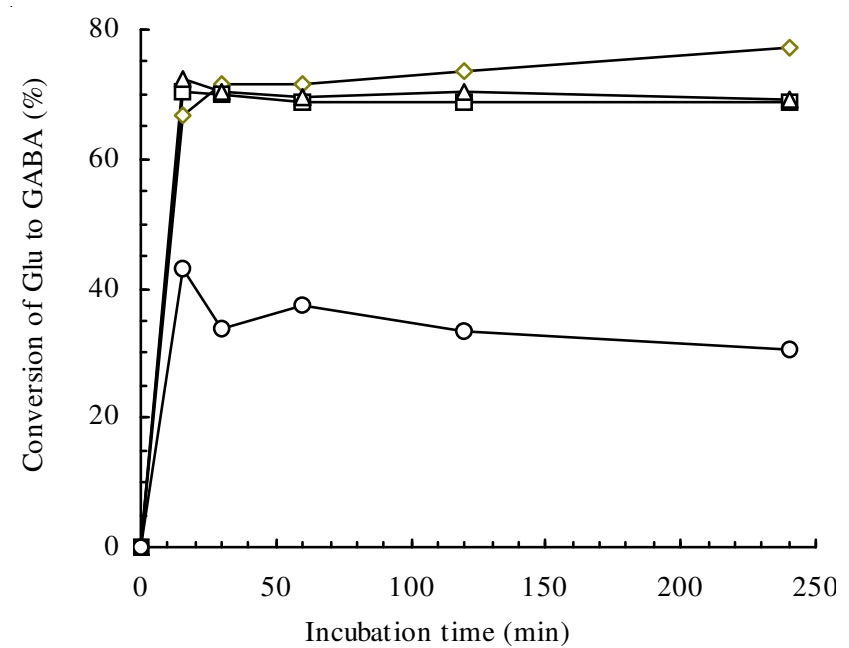

Fig 6 Effect of temperature on the conversion of glutamate to GABA. $\triangleleft-, 30^{\circ} \mathrm{C} ;-\square, 37^{\circ} \mathrm{C} ;-\neg, 50^{\circ} \mathrm{C} ;-\circ-, 70^{\circ} \mathrm{C}$.

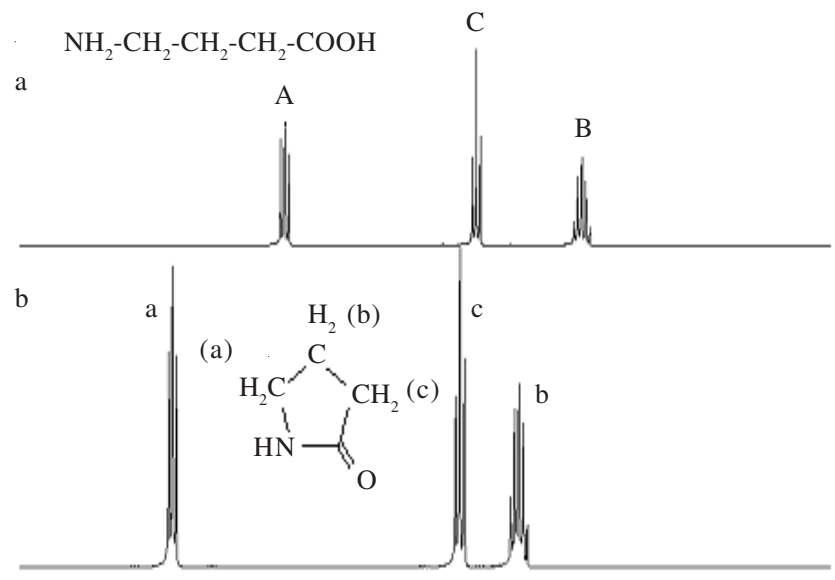

Fig $7{ }^{1} \mathrm{H}$ NMR spectra analysis of GABA (a) and pyrrolidone (b) as the results of heating of GABA.

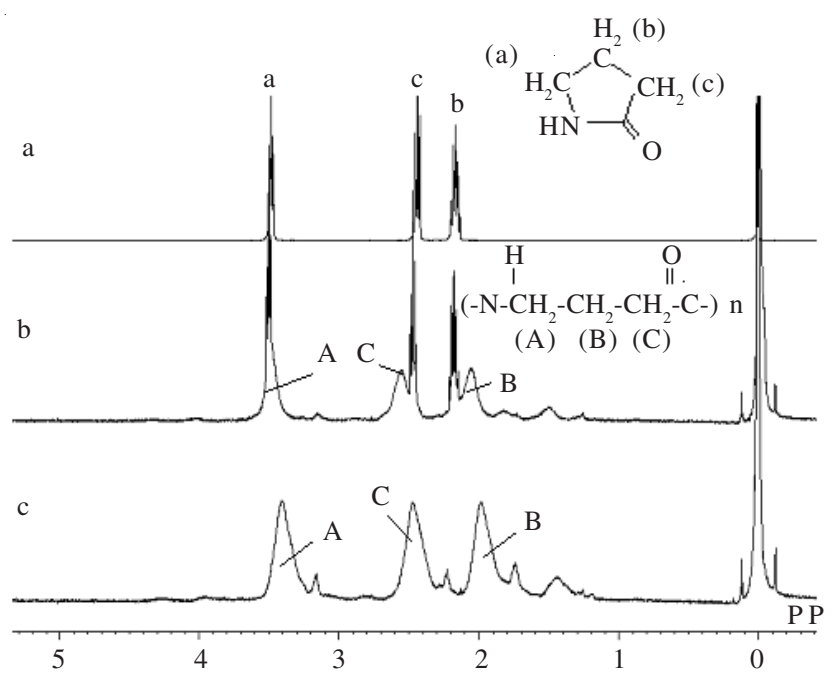

Fig $8{ }^{1} \mathrm{H}$ NMR spectra analysis of pyrrolidone (a), crude polyamide 4 (b) and polyamide 4 after washing with methanol (c).

produced by GAD (EC: 4.1.1.15) from glutamic acid. GABA is representative depressive neurotransmitter in the sympathetic nervous system and has been proved to be effective for lowering the blood pressure of experimental animals and humans. Furthermore, GABA-enriched food is also used as dietary supplement and nutraceutical to help treat sleeplessness, depression and autonomic disorders, chronic alcohol-related symptoms, and to stimulate immune

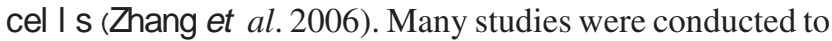
produce GABA especially for the nutraceutical purpose (Nomura et al. 1998; Kono and Himeno 2000; Aoki et al. 2003; Park et al. 2004; Park and Oh 2006).

It is very important to develop the method to produce GABA in massive production. The utilization of microbial GAD in transformation of glutamic acid to GABA seems to be promising method in the future. A lactic acid bacterium is well known in producing GAD that is used in cheese industry to increase the content of GABA in cheese production. However, in this study, E. coli had higher activity of GAD than that of L. lactis when glutamic acid was used as a substrate. GAD is an intracellular enzyme and for that reason the increase of the cell wall permeability controls the substrate access to the enzyme. For that reasons, it seems that the heating and sonication treatment affecting in the cell wall permeability is a one method for increasing the GAD activity of E. coli as shown in the results of this study.

On the other hand, cyclization of GABA to produce pyrrolidone a monomer unit of polyamide 4 and polymerization of pyrrolidone is also play important role in biosynthesis of polyamide 4 . In this study, heating of GABA on $215^{\circ} \mathrm{C}$ for $2 \mathrm{~min}$ is appropriate for cyclization of GABA. Furthermore, the chemical polymerization of pyrrolidone was successfully achieved using sebacoyl chloride $(0.75 \mathrm{~mol} \%)$ as initiator reaction, followed by washing the crude polyamide 4 with methanol.

This study clearly demonstrated that polyamide 4 , the biobased and biodegradable polymer can be biochemically synthesized. This material has a good prospect in the future since the development of bio-based product by using renewable materials as an alternative material to substitute fossil-based products is needed. 


\section{ACKNOWLEDGEMENT}

I would like to thank to Japan International Cooperation Agency (JICA), National Institute of Advanced Industrial Sciences and Technology (AIST) Japan, for giving me a good opportunity to conduct research about biomass technology. I also would to express my sincere gratitude to Naoko Yamano and Atsuyoshi Nakayama for their guidance during my work. I also thank to Sei-ichi Aiba, head of Bio-based Polymers Groups, Research Institute for Innovation in Sustainable Chemistry AIST and all members of his laboratory for their assistance.

\section{REFERENCES}

Aoki H, Uda I, Tagami K, Furuya Y, Endo Y, Fujimoto K. 2003. The production of new tempeh-like fermented soybean containing a high level of $\gamma$-aminobutyric acid by anaerobic incubation with Rhizopus. Biosci Biotechnol Biochem 67:1018-1023.

Hansen J, Sato M, Ruedy R, Lacis A, Oinas V. 2000. Global warming in the twenty-first century: an alternative scenario. Proc Natl Acad Sci USA 97:9875-9880.

Hebert P. 2005. The Kyoto Protocol: In force? (Editorial). Can Med Assoc J 172:437.

Kawasaki N, Nakayama A, Yamano N, Takeda S, Kawata Y, Yamamoto N, Aiba S. 2005. Synthesis, thermal and mechanical properties and biodegradation of branced polyamide 4. Polymer 46:99879993.
Kono I, Himeno K. 2000. Changes in $\gamma$-aminobutyric acid content during ben-koji making. Biosci Biotechnol Biochem 64:617-619.

Nomura H, Kimoto H, Someya Y, Furukawa S, Suzuki I. 1998. Production of $\gamma$-aminobutyric acid by cheese starters during cheese ripening. J Dairy Sci 81:1486-1491.

Nomura N, Kimoto H, Someya Y, Suzuki I. 1999. Novel characteristic for distinguishing Lactococcus lactis subsp. lactis from subsp. cremoris. Int J Syst Bacteriol 49:163-166.

Obst M, Steinbuchel A. 2004. Microbial degradation of poly (amino acid)s. Biomacromolecules 5:1166-1176.

Park KB, Ji GE, Park MS, Oh SH. 2004. Expression of rice glutamate decarboxylase in Bifidobacterium longum enhances $\gamma$ aminobutyric acid production. Biotechnol Lett 27:1681-1684.

Park KB, Oh SK. 2006. Production of yogurt with enhanced levels of $\gamma$-aminobutyric acid and valuable nutrients using lactic acid bacteria and germinated soybean extract. Biores Technol 98:1675-1679.

Plokhov AY, Gusyatiner MM, Yampolskaya TA, Kaluzhsky VE, Sukhareva BS, Schulga AA. 2000. Preparation of $\gamma$-aminobutyric acid using $E$. coli cells with high activity of glutamate decarboxylase. Appl Biochem Biotech 88:257-265.

Rice EW, Johnson CH, Dunnigan ME, Reasoner DJ. 1993. Rapid glutamate decarboxylase assay for detection of Escherichia coli. Appl Environ Microbiol 59:4347-4349.

Tokiwa Y, Calabia BP. 2006. Biodegradability and biodegradation of poly (lactide). Appl Microbiol Biotechnol 72:244-251.

Woodruff RE, McMichael AJ, Hales S. 2006. Action on climate change: no time to delay. Global warming is real, so what are we going to do about it, who will do it, and when? Med J Aust 18:539-540.

Zhang H, Yao HY, Chen F. 2006 Accumulation of $\gamma$-aminobutyric acid in rice germ using protease. Biosci Biotechnol Biochem 70:1160-1165. 